\title{
A Rediscovery of Caddo Heritage: The W. T. Scott Collection at the American Museum of Natural History
}

Robert Cast

Caddo Nation of Oklahoma and Archeological \& Environmental Consultants, LLC

Timothy K. Perttula

Heritage Research Center, Stephen F. Austin State University

Bobby Gonzalez

Bo Nelson

Heritage Research Center, Stephen F. Austin State University

Follow this and additional works at: https://scholarworks.sfasu.edu/ita

Part of the American Material Culture Commons, Archaeological Anthropology Commons, Environmental Studies Commons, Other American Studies Commons, Other Arts and Humanities Commons, Other History of Art, Architecture, and Archaeology Commons, and the United States History Commons

Tell us how this article helped you.

This Article is brought to you for free and open access by the Center for Regional Heritage Research at SFA ScholarWorks. It has been accepted for inclusion in Index of Texas Archaeology: Open Access Gray Literature from the Lone Star State by an authorized editor of SFA ScholarWorks. For more information, please contact cdsscholarworks@sfasu.edu. 
A Rediscovery of Caddo Heritage: The W. T. Scott Collection at the American Museum of Natural History

\section{Creative Commons License}

\section{(c) (1) \&}

This work is licensed under a Creative Commons Attribution-NonCommercial 4.0 International License 


\title{
A Rediscovery of Caddo Heritage: The W. T. Scott Collection at the American Museum of Natural History
}

\author{
Robert Cast, Timothy K. Perttula, Bobby Gonzalez, and Bo Nelson \\ Caddo Nation of Oklahoma and Archeological \& Environmental Consultants, LLC
}

Introduction

Back in August 1997, the Caddo Nation of Oklahoma had submitted a Native American Graves Protection and Repatriation Act (NAGPRA) claim for a cranium that had been obtained by the American Museum of Natural History (AMNH) in New York City in 1877. Very little information was known about these remains, other than it had been obtained "as a purchase/gift" to the museum by Charles C. Jones Jr. and was "found in a mound" somewhere near the "Shreveport vicinity" in Caddo or Bossier Parish, Louisiana. "Bâsed on the presence of artificial cranial deformation," the museum dated these human remains to a period of between A.D. 800 and the contact period. Because of the cranial deformation, and the archeological investigations that had taken place in the past in Louisiana, the museum had determined that the remains were culturally affiliated to the Caddo Nation.

Through consultation with the Caddo Nation of Oklahoma and the Cultural Resources Office staff at the AMNH, in February 2001 the Notice of Inventory Completion was published for these human remains in the Federal Register (Volume 66, No. 35, p. 11043).

In June 2003, with the financial assistance of the AMNH, Bobby Gonzalez and Robert Cast planned 'a visit to the museum. The primary purpose of the trip was to repatriate the skull of this Caddo person under the NAGPRA. The secondary purpose was to look at the ethnographic items culturally affiliated to the Caddo and to further consult with the Cultural Resources Office staff at the AMNH on these and any of the other collections that the Caddo Nation believed to be of significance.

The next day, Bobby and Robert met with the Cultural Resources Office staff of the museum and discussed how the human remains should be handled for safe travel back to Oklahoma. They then looked at all the Caddo ethnographic objects that had been collected over the years by the museum. Bobby made a number of comments concerning the use of specific items and their importance to the tribe. He explained that a number of these items were sold to the museum because many of the Caddo people were in such a desperate state of affairs at the time. From the stories that some of the elders had told him, many of the families that sold items to Mark R. Harrington, did so because they were starving and needed money for food.

During their meetings over the next two days, they asked if any Caddo items were on exhibit in the museum. The staff explained to them that as far as they knew, no. While on a tour of the "Eastern Woodlands People Exhibit," Robert and Bobby spotted a vessel on display with a label clearly identifying this particular vessel (later identified as a Keno Trailed bottle) as "Caddo" (We would also a year later, discover another vessel, a Hodges Engraved bottle, on display. We found out from the museum staff that exhibit items are cataloged in a unique way, not based on any particular cultural affiliation, and most likely would not show up on a database, hence the staff could not have known whether or not any Caddo items were on display). This prompted them 
to further investigate some of the archeological collections that the museum possessed. When asked if they could be provided a print-out based on counties and parishes from what the Caddo Nation considered to be the Caddo "heartland" area, the museum staff printed out an archeological database sheet that in total listed some 390 objects that needed further investigation.

\section{Discovery of The W. T. Scott Collection and Efforts to Document the Collection}

One of the most interesting findings they came across while perusing the archeological database (and where it became more and more obvious that they were going to need to come back to New York) was on one of the headings for the collections which stated: "Locale: TX, Cass County, Site: 1/2 mile from a small creek, Indian Grave."

At this point, Bobby and Robert asked for all of the available information that the museum had in regard to this specific collection. According to Mr. W. T. Scott's handwritten notes and letters that he wrote in 1900, there were actually "17 graves" associated with this collection. They knew at that very moment that they would need to work in a collaborative way to try to obtain grant funding to return to New York and continue this important investigation. It was obvious to them that to document this collection would take the expertise of a number of groups working together, namely the Caddo Nation Cultural Preservation Department, the AMNH Cultural Resources Office staff, and the efforts of the Caddo Nation's archeological consultants.

In February 2004, the Caddo Nation Cultural Preservation Office submitted a National Park Service NAGPRA grant to document the collection first encountered on paper the previous year. In June 2004, the Caddo Nation received notice that their NAGPRA grant (No. 40-04-GP-362) had been funded. In October 2004, Bobby and Robert were back on a plane heading to New York, accompanied by Timothy K. Perttula and Bo Nelson, the Caddo Nation's archeological consultants.

In retrospect, this Caddo person whose skull was obtained by the museum in 1877 (only 42 years after the Caddo had ceded their lands in Louisiana and 18 years after being forced out of the state of Texas) has taken Bobby Gonzalez and Robert Cast on a whirlwind journey from the small town of Binger, Oklahoma (pop. 600) to New York, New York, and back again. They thought at the time that they were the ones, acting out of respect and tribal traditions, that were leading the way and doing something special by bringing this person's remains back home. But just maybe they were the ones being led.

Through all the roles Bobby and Robert have taken on during this past repatriation and now with this current documentation project, their roles, as somewhat self-appointed "NAGPRA detectives" have been the most enjoyable and rewarding. When cultural affiliation with the Caddo can be determined, it has always been the Caddo people's wish to have human remains and funerary objects be brought back together in one place, the way they were originally found, if possible. To do so, takes investigative skills, a little patience, a lot of time, more money than the Caddo Nation has, and the cooperative efforts of everyone with a common interest in these issues.

Working through all the complications, this project is a case study of some of the burdens that are put upon tribal governments, institutions, and researchers who choose to follow and try to fulfill the spirit of NAGPRA. Those of us working in NAGPRA on a regular basis are all too familiar with collections that have been separated and "split up" with human remains stored in one institution while the funerary objects are housed in another, sometimes separated by hundreds, if not thousands, of miles. We are familiar with the Notices of Inventory 
Completions that are published that don't match up with the actual remains and items housed at these institutions. We are familiar with the ongoing legal interpretations that continue to be fought out in federal court regarding the NAGPRA. We are also all too very familiar with the lack of funding for all the parties involved when compared to the amount of work that remains to be done.

These Caddo collections from the American Museum of Natural History represent collections that (1) had never been documented until now, and (2) are part of the unique history of the Caddo Nation in northeastern Texas. The "W. T. Scott" collection now represents more than just a collection of beautiful, artistic, objects, made by a people from the past only to be stored away in a series of dusty drawers. They have now become part of the living history of the great Caddo Nation.

We can define these objects under NAGPRA's legal definitions; give each vessel a specific name based on typology; or expound upon the notion that these items are unique and wonderful "works of art;" however, they are much more than that to the Caddo people. This collection represents a reconnection to and rediscovery of the places, lives, and work of Caddo ancestors.

Past and present archeological and ethnographic research for the areas of Arkansas, Louisiana, Oklahoma, and Texas has shown that the Caddo people have an expansive history in these states long before their removal back to southwestern Oklahoma in 1859 (see Rogers and Sabo 2004). The placement of certain types of artifacts found in mortuary contexts show that the Caddo people had ritual ceremonies for their deceased that are very similar to those they still practice today. By using this research and coordinating with the Caddo Elders of the tribe on their oral histories, religious practices, and what objects would be considered to be of religious or cultural significance, we knew that the "W. T. Scott" collection at the American Museum of Natural History (AMNH) was important to the Caddo people.

Caddo Elders have explained to us that they do not want to ever rebury or improperly handle some other tribal Nation's human remains or items that "were not Caddo." The Caddo Elders that we have talked with consider this taboo and believe that if they were to rebury remains or objects of some other tribe, something bad could happen to the person doing the ceremony and the people involved with the ceremony. In the case of reburying human remains and associated funerary objects that are excavated by archeologists or housed in a museum, the Caddo believe that all the necessary ceremonies were done when this person was originally interred, as evidenced by the items placed in the grave. They also believe that these items should remain together until a proper reburial can be performed. However, the elders who take care of these burial practices, will do a number of things out of respect for the person but will continue to say that the "ceremony was done way back there." They will perform a cleansing ceremony because the burials were disturbed but they do not want to "undo" something that has already been "done."

In a sense, these views presented us with an ultimatum: we needed to know beyond a reasonable doubt whether the human remains, associated funerary objects, unassociated funerary objects, sacred objects, and objects of cultural patrimony as defined by NAGPRA were indeed culturally affiliated to the Caddo Nation based upon the "preponderance of the evidence" according to the NAGPRA.

Partnering up with archeologists may not be suitable for every tribe, but it has worked fairly well for the Caddo Nation. This partnership has for one, provided us with expertise that only strengthens any legal claims we may have to human remains and cultural objects that fall under NAGPRA housed in museums across the United States. Another very practical aspect of this partnership is that the relationships we have developed over the years with the archeological community has given many of the Caddo people an opportunity to learn more 
about archeology. Because of these relationships, we are also (in most cases) kept informed about upcoming proposals and projects that may impact sites of importance to the Caddo.

\section{The W.T. Scott Collection and the Clements Site (41CS25)}

The scope of our current investigations centered on the "W.T. Scott" collection from Cass County, Texas. On our initial visit to the AMNH to repatriate human remains from the museum, we discovered documentation that verified that Mr. Scott had personally excavated this collection from " 17 graves" and had sold the collection to the museum for $\$ 200$ in 1900 . Thanks to the National Park Service NAGPRA grants program, we then put a proposal together that would help us document the items in the collection and begin to justify which items were indeed NAGPRA-related. We came up with a plan of action to photograph and measure all complete vessels, along with describing the vessel types and any decorating characteristics. Selected vessels with unique identifying characteristics would also be drawn. Any of the other items in the collections considered to be archeologically "diagnostic" would also be photographed and documented according to standard archeological citations/references for that type of diagnostic item.

We are fortunate to have a few letters written by Will T. Scott in 1900 concerning his work at the this site in Cass County, Texas. His letters and other later correspondence found in the Texas Archeological Research Laboratory files indicate that his collection came from what was later called the Clements site (41CS25) (Figure 1). That correspondence includes letters written in 1941 between A. T. Jackson and Samuel D. Dickinson-archeologists in Texas and Arkansas, respectively - about the site and its collections. Other primary documents available concerning the history of archeological investigations at the Clements site include Jackson's unpublished 1932 report on the University of Texas work there (Jackson 1932), and an article by Dickinson (1941) entitled "Certain Vessels from the Clements Place, an Historic Caddo Site" published in the Bulletin of the Texas Archeological and Paleontological Society.

Scott indicated in a March 20, 1900 letter to the AMNH that he discovered the site in about 1898 on his farm in Cass County, Texas. He mentioned that the site was $1 / 2$ mile from a small creek, and was on a low knoll. He discovered 17 burials, about 3-6 feet in depth, that contained pottery vessels, stone arrow points, large points, ground stone tools (i.e., he called them tomahawks), and shell necklaces. To interest the AMNH in the purchase of his collection, he suggested the burials and artifacts were left by the Aztec. In a June 20, 1900 letter, however, he asserted that they were in fact Caddo burials, since the "Cadow Indians at one time inhabited the vicinity."

The burials were in rows, with the heads to the north and the feet of the deceased to the south; in Jackson's (1932) later investigations at the site, however, he discovered that almost all the burials were oriented with the head to the east and the feet to the west. Scott also wrote that almost all of the skeletal material in the majority of the graves had disappeared, marked by a "chalky line... where the bones had decayed " (March 20, 1900 letter). The grave goods he found had the large ceramic vessels (jars?) and bowls placed near the feet, with the smaller vessels, including bottles, around the head. The "smallest bottles [were] just under the side of the head at the base of the skull." In the only comments on the association of specific funerary objects in particular burials, Scott wrote to F. W. Putnam of the AMNH that he found blue glass beads in the same grave as two small "phial-shaped" bottles (Figure 2); some of the larger vessels also came from the same grave. The large chipped stone knives were "all in one grave."

In March 1900, W. T. Scott wrote to the AMNH to see if they were interested in purchasing his collection, or what was left of his collection from the site. We know from Dickinson's account that Scott "obtained 


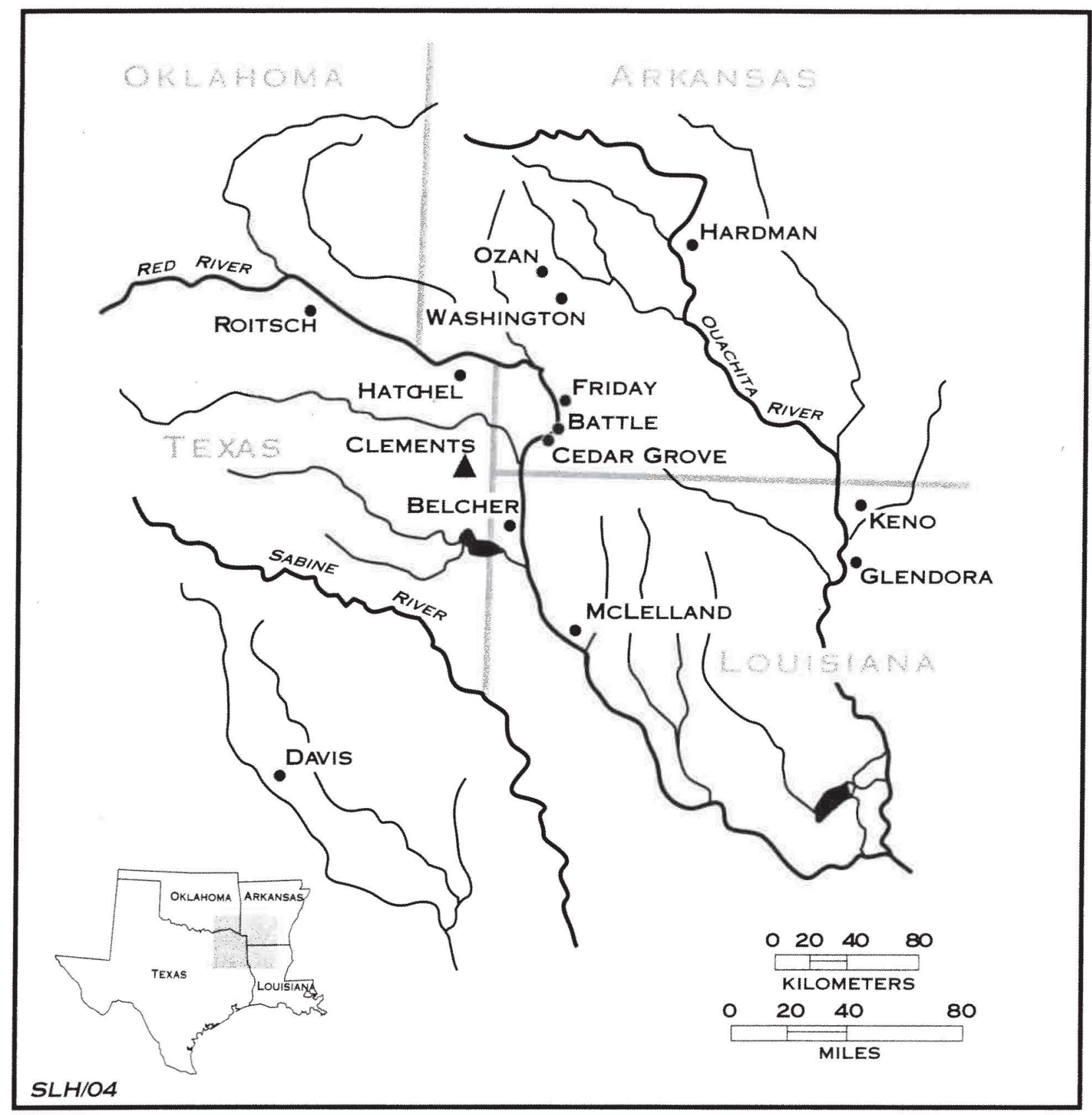

Figure 1. Map of the general location of the Clements site in the southern Caddo area.

a large collection of artifacts [from the Clements site], which he sold and gave to various people" (Dickinson 1941:117). Sometime prior to 1900, Scott had left his farm in Cass County and moved to the town of Gypsum in Hardeman County, Texas, near the Texas Panhandle. In his April 19, 1900 letter, he indicated that he needed the money, and asked for the sum of $\$ 200$ for the collection from the AMNH.

Before the AMNH agreed to purchase the collection from Will Scott, they asked for a catalog of the collections, along with pencil sketches of the pottery vessels and other artifacts (April 9, 1900 letter from F. W. Putnam to Will T. Scott). Scott provided a rudimentary list, along with a series of well-done vessel drawings 


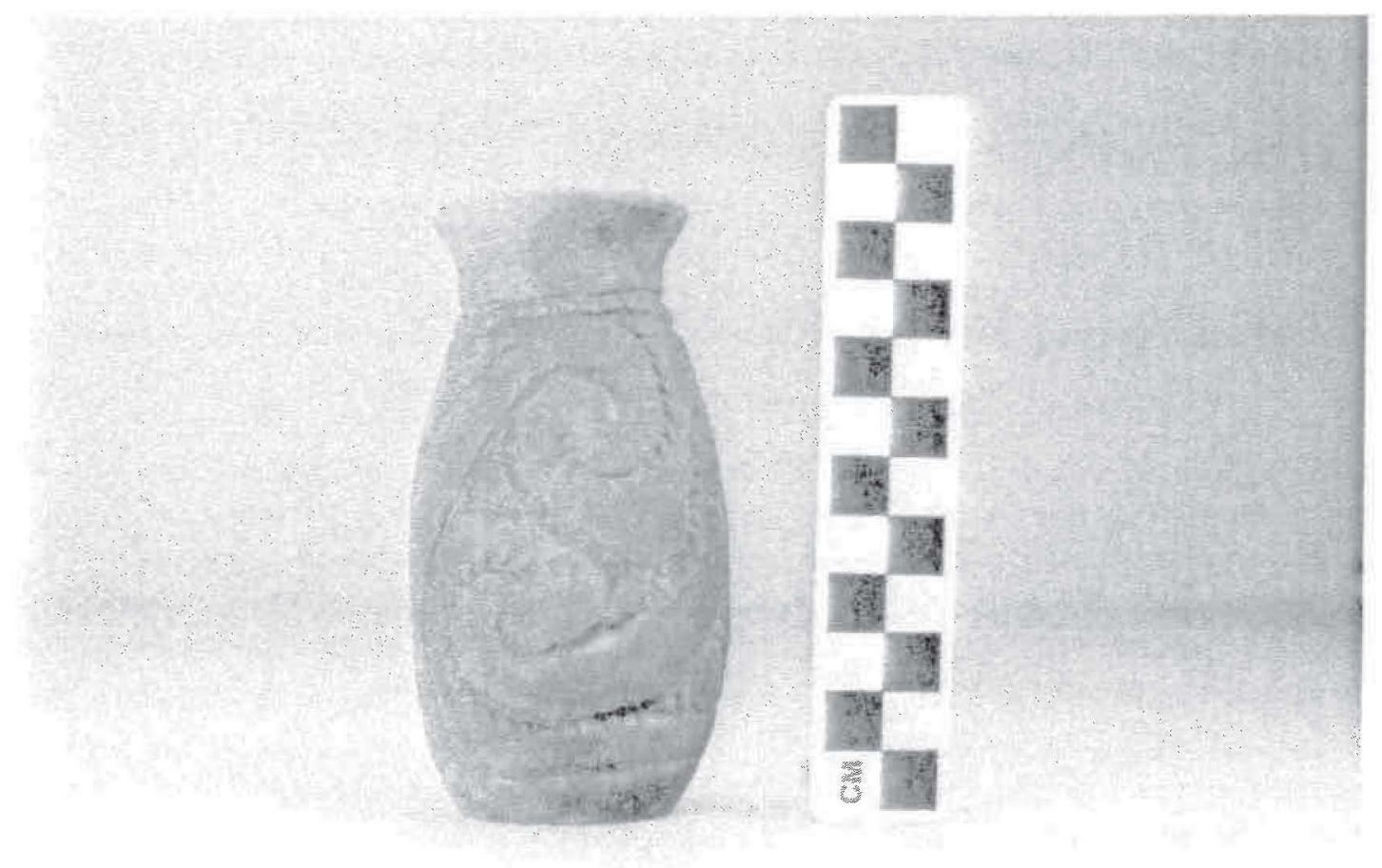

Figure 2. Small and narrow engraved botte (AMNH catalog no. 20.5175) from the W.T. Scont Collection tron the Clements site.

(on file at the AMNH) he had prepared by a Mr. Webber in July 1899. along with six photographs taken by Bonner's in the town of Quanah, Texas. Quanah is the county seat of Hardeman County.

Scott asked for $\$ 200$ for his collection, and the AMNH agreed to that price on May 4. 1900, provided that Scott pack and ship his collection to the museum. Scott apparently shipped the collection on May 17. 1900. The W. T. Scott Collection at the AMNH includes 34 ceramic vessels, two complete ceramic elbow pipes, a small chunk of green clay pigment, three large chipped stone knives made from Central Texas cherts. three ground stone celts, a mussel shell hoe, unmoditied freshwater mussel shell valves, 15 marine shell zoomorphic pendants, six shell ear disks. a single marine shell ear pendant, six barrel-shaped conch shell beads, and 25 medium to large blue glass beads.

Not included in this collection, however, were six ceramic vessels, a shell pendant, and a shell bead that Will Scott gave to his sister, Mrs. C. A. Smith (Dickinson 1941:117). The vessels eventually made their way to Samuel D. Dickinson. These six or seven vessels ("of the finest pieces of pottery" in the Scot collection) included two Hodges Engraved bottles (Dickinson 1941: Plate 19. nos. 1 and 2), two Cass Appliqued jars (Dickinson 194!: Plate 20, Nos, I and 2), two dininutive engraved bottes (Dickinson 1941: Plate 21, Nos. 2 and 3) that are much like two bottes now in the AMNH collection (see Figure 2), and a unique bi-lohed Hodges Engraved bottle (Dickinson 1941: Plate 21. No. 1). The vessel shape is reminiscent of a four-lobed Keno Trailed botte vessel illustrated by Moore (1909: Figure 81) from the Glendora site in northern Louisiana, as well as to another four-lobed Belcher Engraved bonle from the Foster site (Moore 1912: Plate XLIV) along the Red River. 
We know that the Clements site is a late 17th to early 18th century (ca. 1680-1720) Nasoni Caddo site in Cass County, Texas, in the northeastern part of the state. It is situated on a knoll near the headwaters of Black Bayou, a stream that flows in a southeasterly direction for a few miles to its confluence with the Red River near the Belcher mound site (16CD13, see Webb 1959). The site is also not far from the headwaters of streams flowing into the Sulphur River, another major tributary to the Red River, and only a few miles west of the Caddo Trace. The Caddo Trace was an aboriginal trail that led from the Hasinai Caddo settlements in East Texas to the Kadohadacho settlements on the Red River in the general area of Texarkana, Texas. The Goode Hunt site (41CS23), about 5 miles to the west of the Clements site, is a contemporaneous early historic Caddo settlement (see Perttula 1992). Two other Caddo cemeteries of similar kind and age in the vicinity include the A. P. Fourche and R. A. Simpson farm sites on Black Bayou and Black Cypress Bayou. These cemeteries had burials accompanied by glass trade beads, large well-made chert bifaces or knives, and numerous aboriginal ceramic vessels.

The Clements site was next excavated by the University of Texas in 1932 (Jackson 1932; Lewis 1987). At that time, 22 Caddo burials were exposed over a 600 square meter area adjacent to a small midden deposit. Twenty of the burials were apparently single, primary extended inhumations, but a semi-flexed burial (Burial 2) was also recorded, along with a multiple individual (Burial 11) containing three individuals. According to Jackson (1932), the three individuals are from three superimposed primary extended burials rather than the product of one burial event, which is a very rare if not unique mortuary context for prehistoric or early historic Caddo burials.

There were apparently several different burial groupings at the Clements site. This is based more than anything on the size and orientation of the burial pits across the cemetery, but the kinds of funerary objects placed with the individuals may help to differentiate the age and sex of the deceased along with their status as well as the status of their lineage.

Jackson (1932) had noted that the site had been disturbed prior to the University of Texas excavations. Much of the skeletal remains had been moved and rearranged, and many artifacts had been removed from the graves. As we know now, this disturbance to the Clements site burials was the result of extensive digging by W. T. Scott and others, who dug 17 burials here, but removed no skeletal remains. Jackson (1932) indicated that the site had been discovered about 1900, when we know from Scott's letters that it must have been a few years before that, since his collection from the Clements site was sold to the AMNH in 1900. Jackson was unaware that any of Scott's collection had been sold to the American Museum of Natural History, although he had been told that "about a dozen vessels from this site were sent to the Smithsonian Institution at that time [1900]." Since there are no materials from the Clements site at the Smithsonian Institution, we suspect that this inaccurate information actually was referring to the materials sold by Scott to the AMNH. Jackson was aware of Scott's considerable digging at the site, and he also knew about a small collection of ceramic vessels from the Clements site that were in the hands of Samuel D. Dickinson of Prescott, Arkansas (Jackson 1932). Dickinson, a well-known archeologist at the time in Arkansas, received these vessels from the daughter of Will Scott's sister, a Mrs. J. B. Hesterly of Prescott, Arkansas (Dickinson 1941:118).

Nevertheless, a relatively diverse assemblage of funerary objects was recovered from the site during Jackson's work at the Clements site, as well as in Scott's digging. Conch shell ornaments made from Gulf Coast marine shells were the most common item placed with the deceased, including probable bead necklaces from at least three burials (Burials 2,8, and 15), bracelets (Burial 15), ear discs, and portions of pendant necklaces. The zoomorphic style of the conch shell pendants from the Clements site (Figure 3) is very similar to ones recovered at both the Belcher (Webb 1959:172-173) and Cedar Grove (Kay 1984: Figure 13-22) sites, as well 


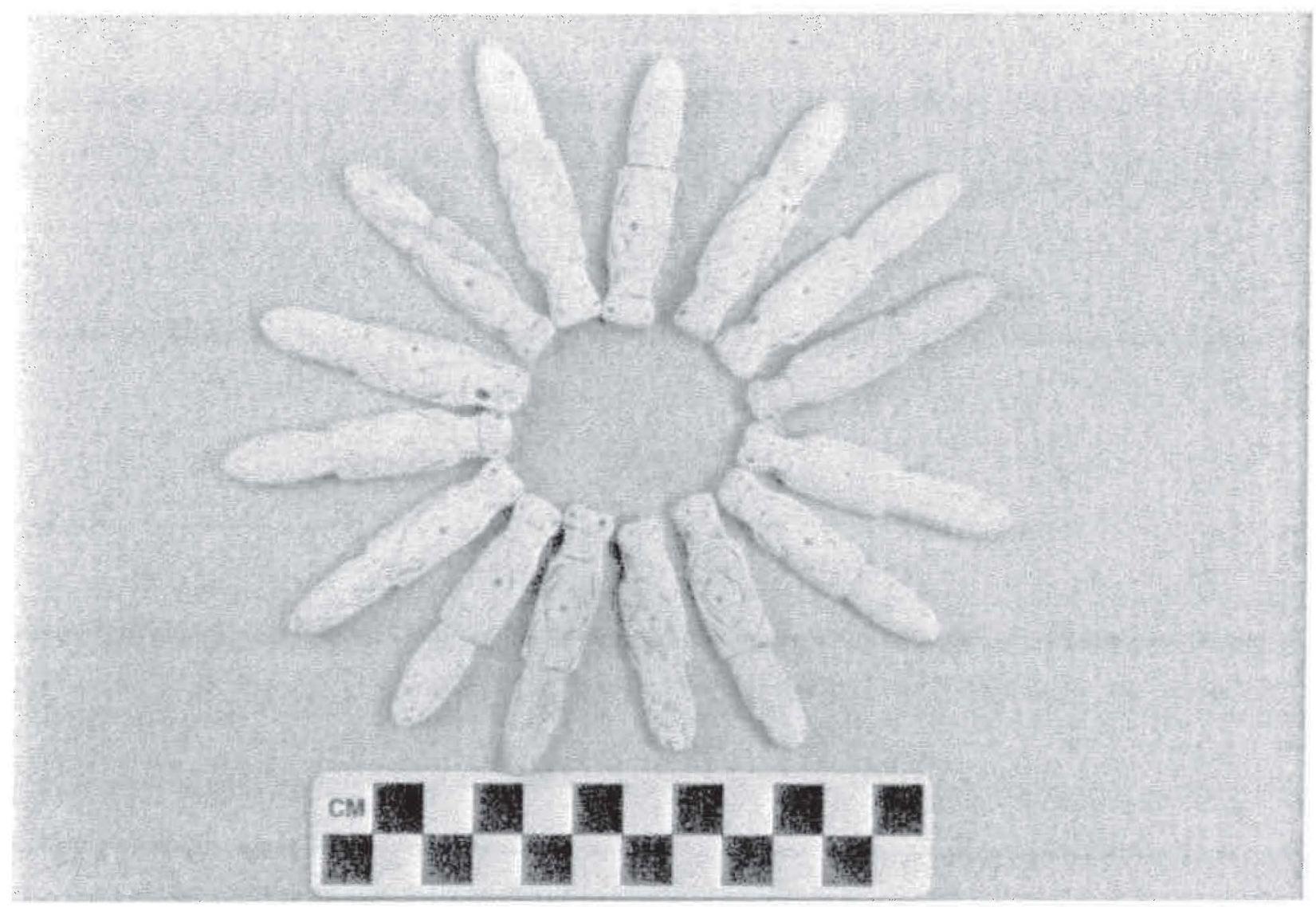

Figure 3. Engraved zoomorphic pendants from the W. T. Scott Collection (AMNH catalog no. 20-5156).

as from Belcher phase components at the Foster, Friday, and Battle sites along the Red River in southwestern Arkansas.

Half of the Clements burials had conch shell ormaments, certainly indicative of a ready access to these materials of exotic origin; a similar relationship was noted in the Chakanina phase burials at the Cedar Grove site (Trubowizz 1984; Pertula 1992: Table 16). Along with the shell omaments were European glass beads (1-26 beads per burial) from five separate interments at Clements. In two instances, shell beads or other shell omaments were found together in the same burial with the European glass beads. The 25 blue glass beads in the W. T. Scott collection from the Clements site were apparently found together with the small and narrow engraved bottles (see Figure 2).

Pottery vessels were also commonly placed as funerary objects in the burials, with as many as nine vessels placed with Burial 11 . Others had between 1-6 vessels per burial. In the W. T. Scott Collection, there are 15 spool-necked bottles, two simple bowls (including a bird effigy bowl). 10 carinated bowls, two compond bowls, and five jars. The principal ceramic types among the bottes, bowls. carinated bowls, and compound bowls include Keno Trailed ( $\mathrm{n}=2$ ), including one Keno Trailed, var. Phillips bowl (Figure 4). Hodges Engraved $(n=7$. Figure 5), Thylor Engraved ( $n=6$. Figure 6), and Simms Engraved $(n=5)$.

One of the botles had red-slipped scrolls and triangular areas (repeated live times) in relief across the body and at the base (Figure 7). The red-slipped areas around the serols have been scraped away to emphasize the scroll itedf. The scraped areas show the original color of the pottery vessel before it was slipped. This is a new 

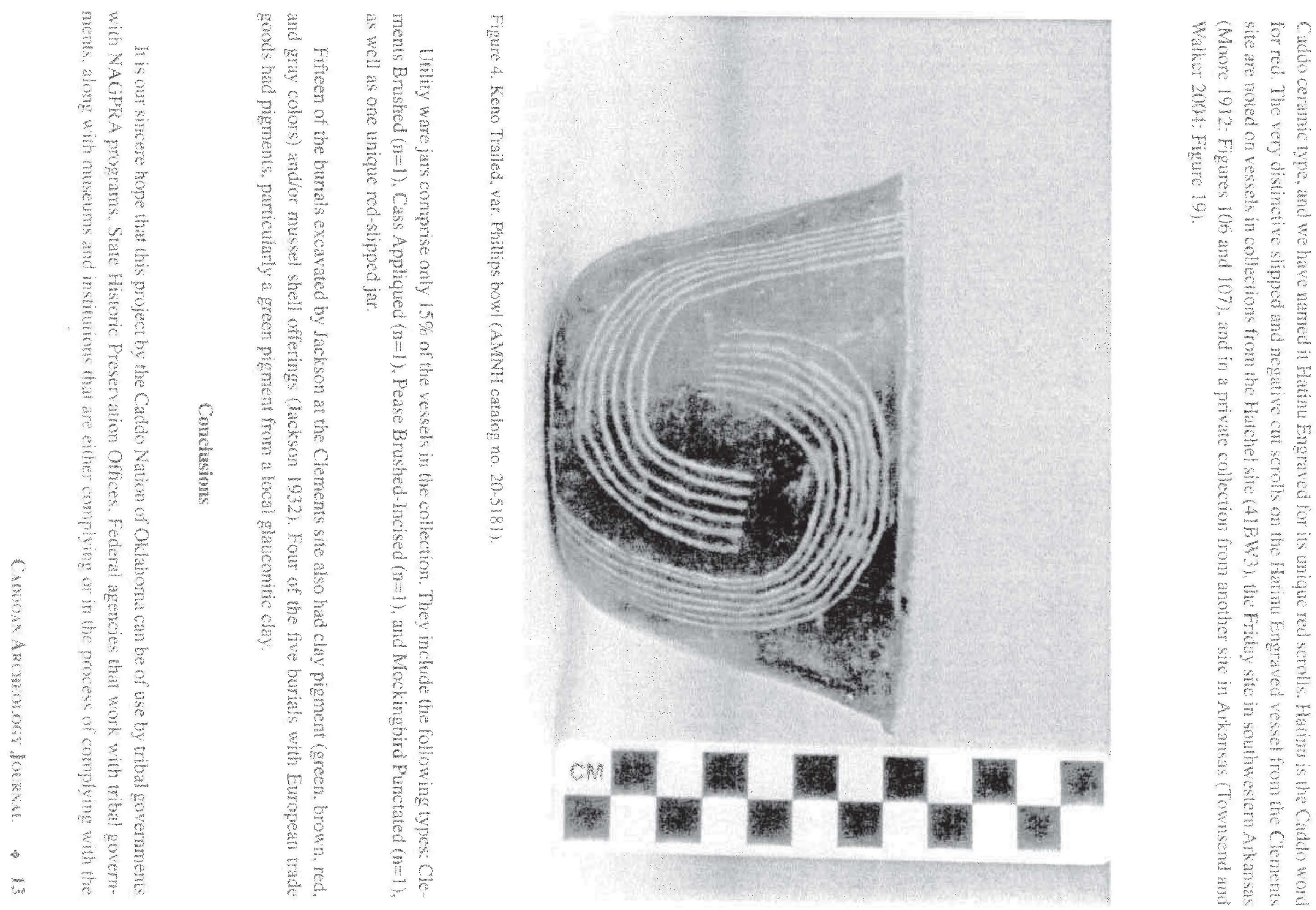


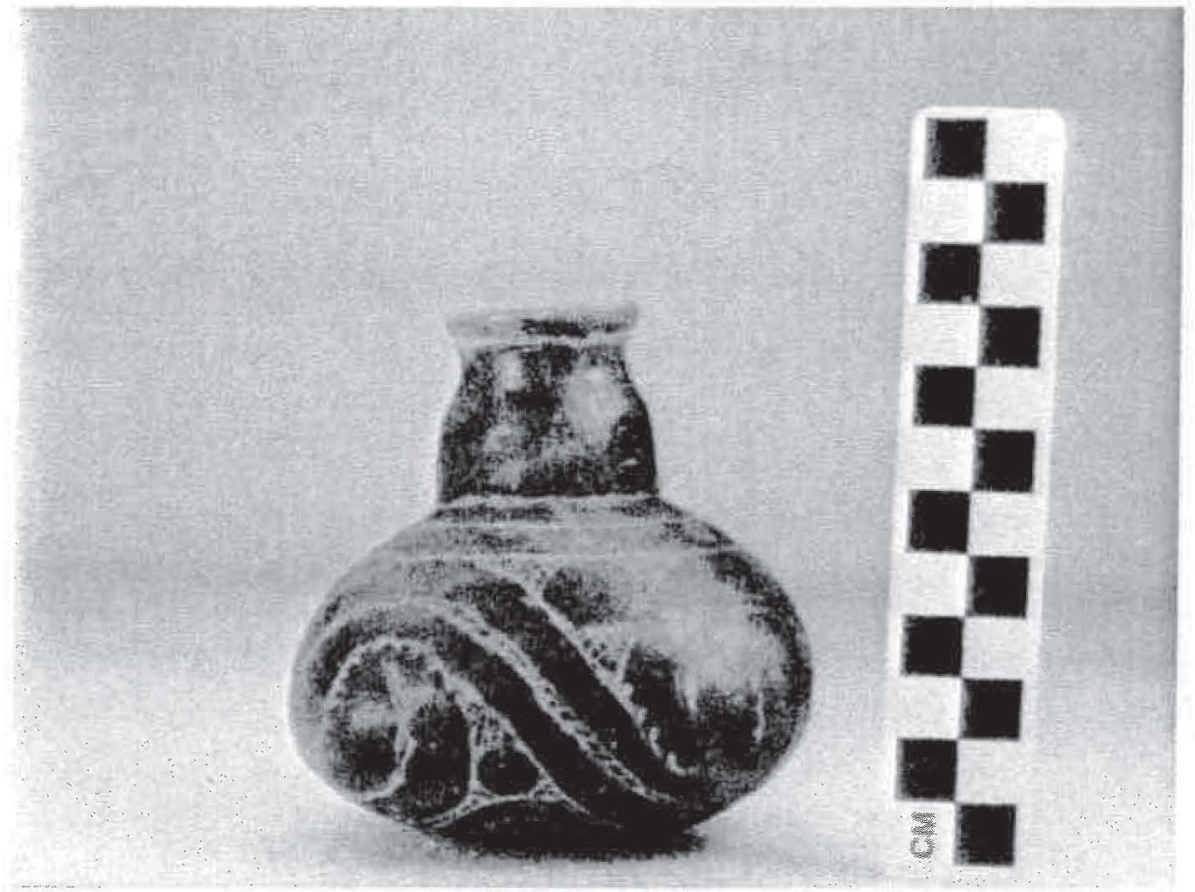

Figure 5. Hodges Engraved bottle (AMNH catalog no. 20-5173).

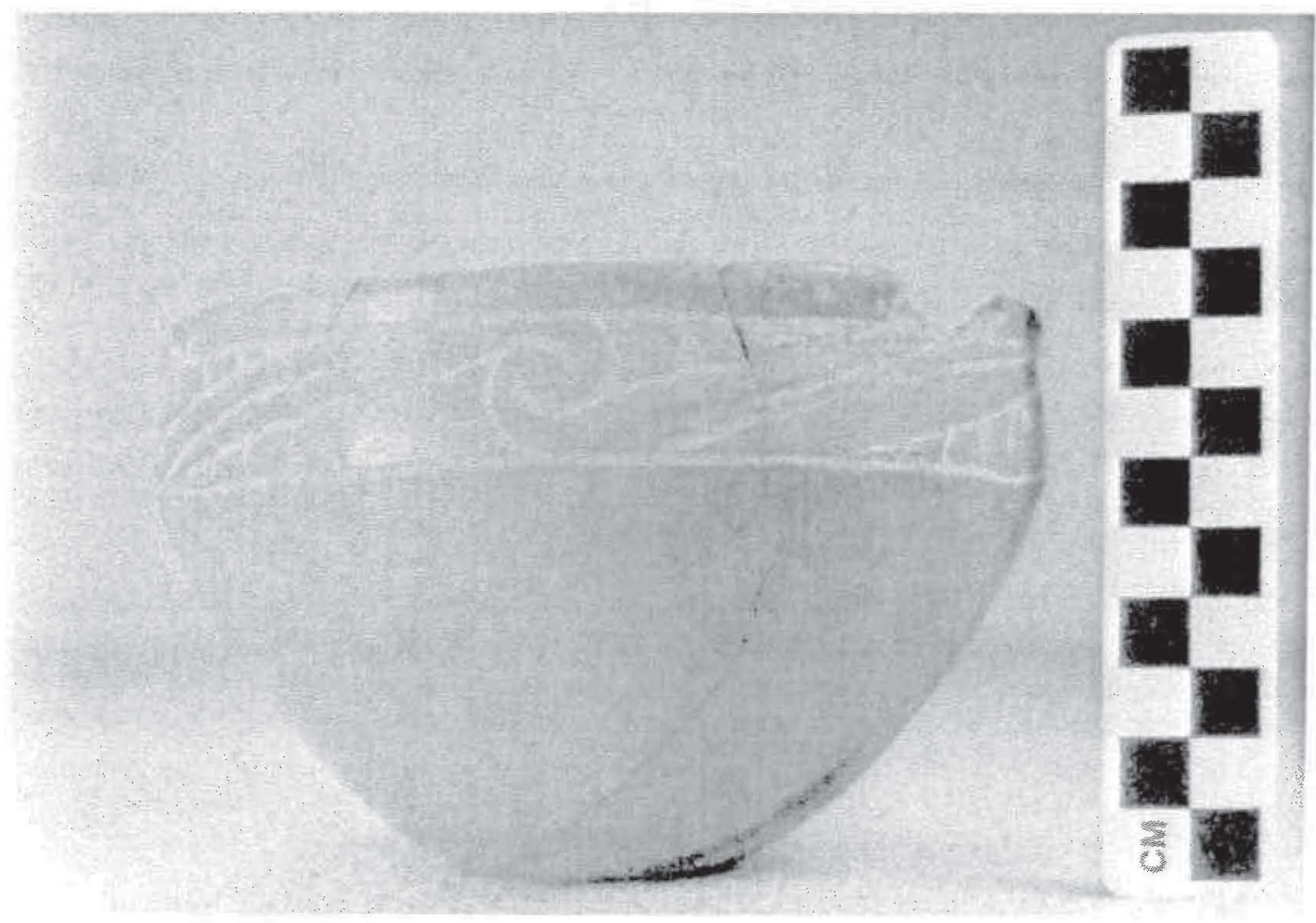

Figure 6. Taylor Engraved red-slipped carinated bowl (AMNH catalog no. 20-5182). 


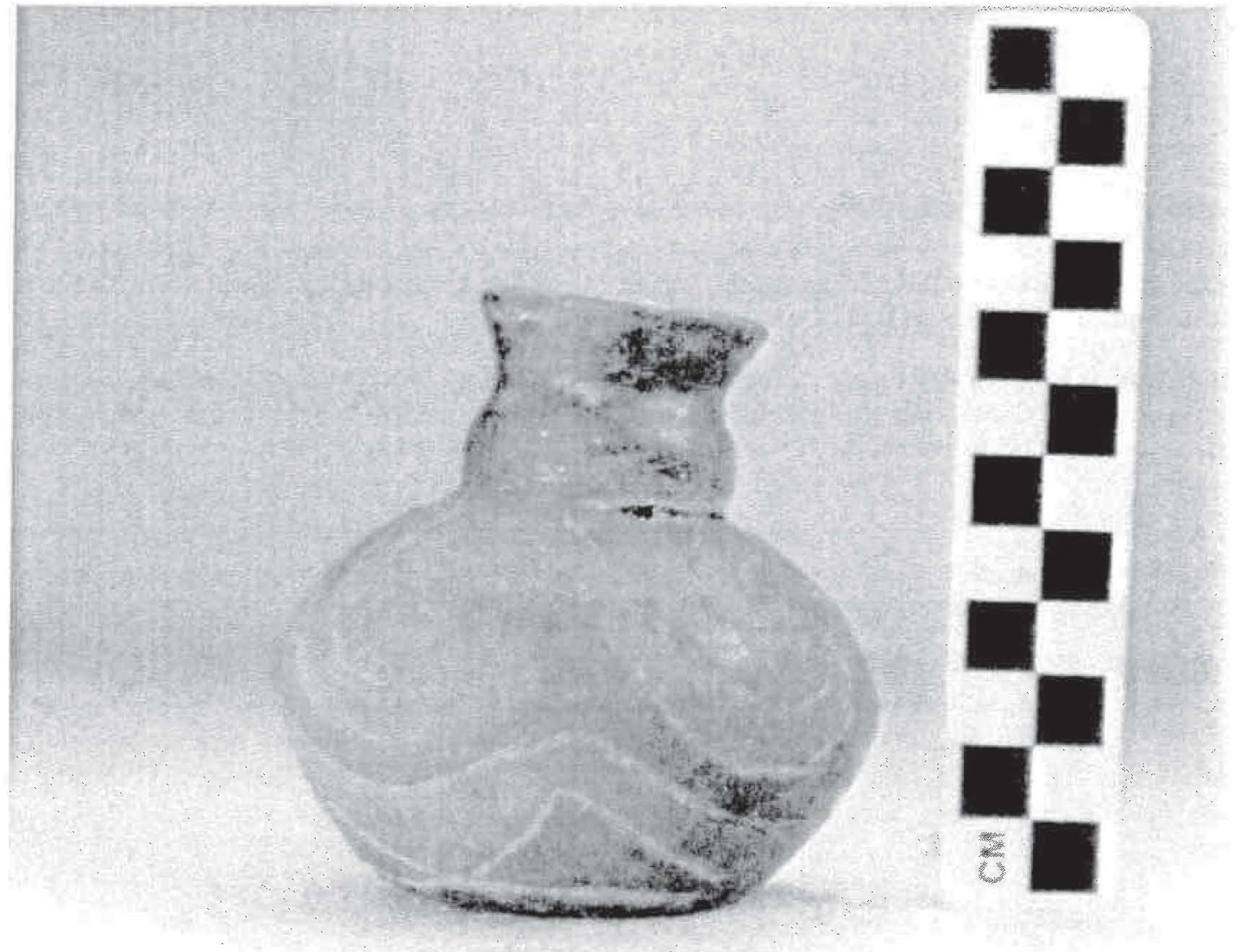

Figure 7. Hatinu Engraved bottle (AMNH catlog no. 20-5170).

NAGPRA. Our goals were twofold: one was to document the collections at the AMNH and prepare a report of our findings; the report will be published and distributed by the Caddo Nation in 2005. Our other goals were a litte broader in their reach: to heighten the awareness of NAGPRA; reveal some of its real life complications: and suppost the continued need for cooperative efforts between the archeological and tribal communities.

\section{References Cited}

Dickinson, S. D.

1941 Cerain Vessels from the Clements Place, an Historic Catdo Site. Bulletin of the Texas Archeological and Paleontological Society $13: 117-134$

$\operatorname{Jacksm}, \mathrm{A} . \mathrm{T}$.

1932 Exploration of a burid she on Clements Bros. Furn in Cas Couny. Texas. MS on wile, Texas Areheological Research Lahoratory. The University of Texas at Austin.

Kay. M.

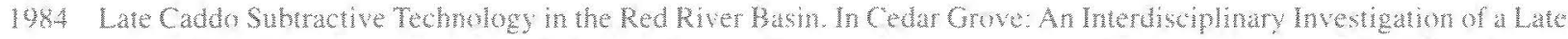
Caddo Farmstead in the Red River Valley. edited by N. 1. Trubowitz. pp. 174-206. Research Sertes No. 23. Arkansw Archeological Survey, Fayetreville.

Lewis. G.A.

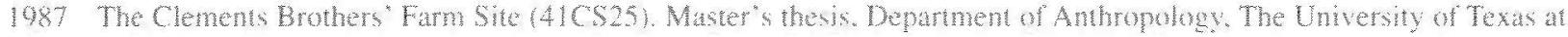
Austin. 
Moore, C. B.

1909 Antiquities of the Ouachita Valley, Joumal of the Academy of Natural Sciences of Philadelphia 14:1-170.

1912 Some Aboriginal Sites on Red River. Joumal of the Academy of Nutural Sciences of Philadelphia 14:481-644.

Pertula, T. K

1992 "The Caddo Nation": Archaeological and Ethnohistoric Perspectives. University of Texas Press, Austin.

Rogers, J. D. and G. Sabo III

2004 Caddo. In Handbook of North American Indians, Volume 14, Southeast, edited by R. D. Fogelson, pp. 616-631. Smithsonian Institution, Washington, D.C.

Townsend, R. P. and C. P. Walker

2004 The Ancient Art of Caddo Ceramics. In Hero. Hawk, and Open Hand: American Indian Ant of the Ancient Midwest and South, edited by R. P. Townsend, pp. 231-245. Art Institute of Chicago and Yale University Press. Chicago and New Haven.

Trubowitz, N. L. (editor)

1984 Cedar Grove: An Interdisciplinary Investigation of a Late Caddo Farmstead in the Red River Valley. Research Series No. 23. Arkansas Archeological Survey. Fayetteville.

Webb, C. H.

1959 The Belcher Mound: A Stratified Caddoan Site in Caddo Parish. Louisiana. Memoirs No. 16. Society for American Archaeology, Salt Lake City. 